FITRAH Jurnal Kajian Ilmu-ilmu Keislaman

Vol. 04 No. 1 Juni 2018

e-ISSN : 2460-2345, p-ISSN: 2442-6997

Web: jurnal.iain-padangsidimpuan.ac.id/index.php/F

\title{
IMPLIKASI PELAKSANAAN SURAT EDARAN MAHKAMAH AGUNG (SEMA) NOMOR 3 TAHUN 2014 TERHADAP EKSISTENSI UNDANG - UNDANG NOMOR 1 TAHUN 1974
}

\author{
ADI SYAHPUTRA SIRAIT \\ IAIN Padangsidimpuan \\ adisyahputra.sirait@gmail.com
}

\begin{abstract}
Abtract
Supreme Court Circular (SEMA) number 3 in 2014 concerns about inspection of case voluntary of marriage confirmation, it's a solution for the problems that occur in all districts /cities in Indonesia related to Population Administration which is a mandate of Law Number 23 of 2006 and Presidential Regulation Number 25 of 2008, the circular letter is still a reference for Religious Courts in Indonesia to determine marriages that are not registered by the Office of Religious Affairs. In substantially, SEMA can reveal the problems that's the individual rights of the Indonesian people about attendance, protection and recognition of the determination of the legal status of a person, but on the other hand SEMA has implications for the existence of Law Number 1 of 1974 which still has a rule and reference in implementation of marriage in Indonesia. The Circular Letter of Supreme Court (SEMA) is basically a technical guideline or implementation manual that must be submit to the principles of Lex Specialis Derogat Legi Generalis. So that it cannot be contradicted with the Law, moreover it can weaken the implementation of the law.
\end{abstract}

Keywords : implication, Supreme Court Circular(SEMA), Exitential and law of Number 1 in 1974

\begin{abstract}
Abstrak
Surat Edaran Mahkamah Agung (SEMA) Nomor 3 Tahun 2014 tentang Pemeriksaan Kasus Sukarela Isbat Nikah adalah solusi atas permasalahan yang terjadi di semua kabupaten / kota di Indonesia terkait Administrasi Kependudukan yang merupakan amanat Undang-Undang Nomor 23 Tahun 2006 dan Peraturan Presiden Nomor 25 Tahun 2008, surat edaran tersebut masih menjadi acuan bagi Pengadilan Agama di seluruh Indonesia untuk menentukan pernikahan yang tidak terdaftar oleh Kantor Urusan Agama. Secara substansi, SEMA dapat mengungkap masalah-masalah yang merupakan hak individu masyarakat Indonesia terhadap layanan, perlindungan dan pengakuan terhadap penentuan status hukum seseorang, tetapi di sisi lain SEMA memiliki implikasi terhadap keberadaan Undang-Undang Nomor 1 Tahun 1974 yang masih merupakan aturan dan acuan dalam pelaksanaan pernikahan di Indonesia. The Supreme Court Circular (SEMA) pada dasarnya adalah pedoman teknis atau petunjuk implementasi yang harus tunduk pada prinsip-prinsip Lex Specialis Derogat Legi Generalis. Sehingga tidak dapat dipertentangkan dengan UU di atasnya, apalagi melemahkan pelaksanaan hukum.
\end{abstract}

Kata Kunci: Implikasi, Surat Edaran Mahkamah Agung, Eksistensi dan Undang - undang Nomor 1 Tahun 1974 
FITRAH Jurnal Kajian Ilmu-ilmu Keislaman

Vol. 04 No. 1 Juni 2018

\section{PENDAHULUAN}

Indonesia merupakan negara hukum sebagaimana yang telah dirumuskan dalam Undang-Undang Dasar Negara Republik Indonesia Tahun 1945 (UUD 1945) ${ }^{1}$ bahwa Indonesia adalah negara hukum (Rechtstaat ${ }^{2}$ ) bukan negara yang berdasarkan atas kekuasaan (matchstaat) semata - mata, artinya segala tindakan yang dilakukan oleh Negara dan masyarakat Indonesia harus berdasarkan hukum yang berlaku di negara Indonesia dengan menjunjung tinggi kedaulatan hukum, sebagai negara hukum, maka hukum haruslah menjadi prinsip utama dalam mengatur kehidupan masyarakat, tidak terkecuali dalam hal menghalalkan hubungan antara laki - laki dengan perempuan (Perkawinan).

Di Indonesia, Perkawinan diatur sedemikian rupa, sebab perkawinan merupakan institusi yang sangat penting dalam masyarakat. Eksistensi institusi ini adalah melegalkan hubungan hukum antara seorang laki - laki dengan seorang perempuan sebagaimana yang diatur dalam Undang - Undang Nomor 1 Tahun 1974, dimana yang dimaksud perkawinan adalah ikatan lahir batin antara seorang pria dan wanita sebagai suami isteri dengan tujuan untuk membentuk keluarga (rumah tangga) yang bahagia dan kekal berdasarkan Ketuhanan Yang Maha Esa. ${ }^{3}$

Suatu perkawinan baru dapat dikatakan sebagai perbuatan hukum apabila dilakukan menurut ketentuan hukum yang berlaku secara positif. ${ }^{4}$ Ketentuan hukum yang mengatur mengenai tata cara perkawinan yang dibenarkan oleh hukum adalah seperti yang diatur dalam undang - undang No. 1 tahun 1974 dan PP No 9 tahun 1975. Sehingga perkawinan ini akan mempunyai akibat hukum yaitu akibat yang mempunyai hak mendapatkan pengakuan dan perlindungan hukum. ${ }^{5}$

Namun, fenomena perkawinan sirri atau perkawinan di bawah tangan yang masih banyak terjadi di kalangan masyarakat kita, baik yang dilakukan oleh masyarakat biasa maupun figur - figur yang dikenal publik. Isu - isu

${ }^{1}$ Pasal 1 ayat 3 (perubahan III)

${ }^{2}$ Istilah rechtstaat pertama kali digunakan oleh Rudolf van Gnes (1816-1895), seorang guru besar di Berlin-Jerman pada awal abad ke 19 sebagai konsepsi baru dari ide rule of law. Istilah ini terdapat dalam bukunya yang berjudul "Englishce verwaltunngerechte" pada tahun 1857 dimana ia menggunakan istilah Rechtstaat untuk pemerintah negara Inggris

${ }^{3}$ R. Subekti, Pokok - pokok Hukum Perdata (Jakarta : PT. Pradnya Paramita,1999). hlm. 557

${ }^{4}$ Nasruddin Salim, "Isbat Nikah Dalam Kompilasi Hukum Islam (Tinjauan Yuridis Filosofis Dan Sosiologis)", dalam Mimbar Hukum Aktualisasi Hukum Islam, No. 62 THN XIV, (Jakarta : AlHikmah dan DITBINBAPERA Islam, 2004), hlm. 67

${ }^{5}$ Nasruddin Salim, "Isbat Nikah Dalam..., hlm. 67 
seputar perkawinan sirri masih menjadi bahan perbincangan banyak pihak, apalagi jika praktik tersebut dilakukan oleh orang - orang yang memang dikenal luas oleh masyarkat. Yang paling menyita perhatian adalah kasus perkawinan sirri antara Machicha Muchtar dan Moerdiono.

Kasus ini bahkan sampai melibatkan Mahkamah Konstitusi, karena pihak Machicha Muchtar mengajukan Judicial Riview terhadap pasal 43 Undang undang Nomor 1 tahun 1974 Tentang Perkawinan. Mahkamah Konstitusi bahkan mengabulkan permohonan Machicha dengan melakukan amandemen terhadap pasal tersebut sehingga bunyi pasalnya menjadi berubah dan menguntungkan pelaku perkawinan sirri. ${ }^{6}$

Pada hakikatnya perkawinan sirri dari perspektif Agama adalah sah, jika rukun dan syaratnya terpenuhi. Namun demi menjaga ketertiban, negara berhak mengatur masalah perkawinan, sehingga perkawinan hendaknya dicatatkan pada Petugas Pencatat Perkawinan (Bagi orang islam). Hal ini sesuai dengan bunyi pasal 2 ayat 2 Undang - undang No. 1 tahun 1974 bahwa "tiap - tiap perkawinan dicatat menurut peraturan perundang - undangan yang berlaku". ${ }^{7}$ Kemudian dalam Peraturan Pemerintah Nomor 9 tahun 1975 pada Bab II Pasal 2 dan 3 masalah pencatatan perkawinan dijelaskan kembali. ${ }^{8}$

Pencatatan pernikahan merupakan amanah Undang - undang untuk dilaksanakan agar seluruh keluarga dapat tercatat secara nasional dan anak yang dilahirkan dari keluarga tersebut juga mendapatkan hak yang sama dimata hukum dan negara. Namun pada kenyataannya tidak semua masyarakat sadar akan hal itu, dibuktikan dengan banyaknya pelaksanaan isbat nikah oleh pengadilan agama di seluruh Indonesia, berdasarkan data yang dihimpun oleh Direktorat Pembinaan Administrasi Peradilan Agama Ditjen Badilag, sepanjang tahun 2017 pelayanan terpadu terselenggara di 362 lokasi dan jumlah perkara yang disidangkan sebaganya 16. 392, sedangkan pada tahun sebelumnya, pelayanan terpadu terselenggara di 69 lokasi dan jumlah perkara yang disidangkan sebanyak $1.976 .^{9}$

Pencatatan Pernikahan dianggap penting karena ditujukan sebagai upaya untuk mewujudkan ketertiban perkawinan dalam masyarakat, melindungi

${ }^{6}$ Putusan MK No. 46/PUU - VIII/2010 menyatakan bahwa anak yang lahir di luar kawin mempunyai akibat hukum dengan ayah biologisnya, tidak lagi hanya dengan keluarga ibu.

${ }^{7}$ Undang - undang Perkawinan No. 1 tahun 1974 (Surabaya : Pustaka Tintamas, t,t), hlm.8

8 Pasal 2 dan 3 masing - masing terdiri dari 3 ayat

${ }_{9}^{9}$ Berita Mahkamah Agung RI (Direktorat Jenderal Badan Peradilan Agama) 
FITRAH Jurnal Kajian Ilmu-ilmu Keislaman Vol. 04 No. 1 Juni 2018

kesucian perkawinan sebagai sebuah nilai dan ikatan yang sakral, ${ }^{10}$ dan secara khusus ditujukan untuk melindungi kaum perempuan dalam kehidupan rumah tangga. Hubungan perkawinan mengikat secara lahiriah dan batiniah antara seorang laki - laki dan perempuan sebagai bentuk kemaslahatan (bernilai baik dan tertib) yang merupakan dasar universal bagi penetapan suatu hukum.

Pencatatan perkawinan pada prinsipnya merupakan hak dasar (hajjiah) dalam keluarga. Selain itu merupakan upaya perlindungan terhadap isteri maupun anak dalam memperoleh hak - hak keluarga seperti hak waris dan lain - lain. Pencatatan perkawinan tidak diatur di dalam nash baik al-Qur'an maupun sunnah. Pencatatan perkawinan dianggap sebagai salah satu solusi terhadap kondisi demikian, bertitik tolak dari hal tersebut maka pencatatan perkawinan dianggap sebagai salah satu bentuk pembaharuan hukum (reformasi hukum) keluarga yang dilakukan oleh negara - negara dunia islam.

Pencatatan perkawinan merupakan suatu bentuk pembaharuan hukum yang dilakukan dalam bidang hukum keluarga Islam dalam bentuk Lex Humana atau (Hukum Manusia) yang mengatur hubungan antara manusia dalam suatu masyarkat tertentu dalam kerangka tuntutan - tuntutan khusus dalam masyarakat.11 Hal ini disebabkan oleh tidak diungkapkannya keharusan pencatatan perkawinan di dalam Al-Qur'an dan sunnah. Atas dasar inilah para ulama fiqih juga tidak memberikan perhatian serius terhadap pencatatan perkawinan. Dan undang - undang mengamanahkan pencatatan ini kepada KUA dimana domisili calon memepelai wanita.

Dalam perkembangan selanjutnya dengan terbitnya Keputusan Menteri Agama (KMA) Nomor 517 tahun 2001 tentang penataan Organisasi Kantor Urusan Agama Kecamatan, maka Kantor Urusan Agama (KUA) berkedudukan di wilayah kecamatan dan bertanggung jawab kepada Kepala Kantor Departemen Agama Kabupaten/Kota yang dikoordinasi oleh Kepala Seksi Urusan Agama Islam/Bimas dan Kelembagaan Agama Islam dan dipimpin oleh seorang kepala yang mempunyai tugas pokok melaksanakan sebagian tugas Kantor Departemen Agama Kabupaten/Kota di Bidang Urusan Agama Islam dalam wilayah kecamatan. Dengan demikian, eksistensinya KUA Kecamatan sebagai institusi pemerintah dapat diakui keberadaannya, karena memiliki

\footnotetext{
${ }^{10}$ Aburrahman, Perkawinan Dalam Syari'at Islam, (Jakarta : Rineka Cipta, 1992), hlm. 1

${ }^{11}$ Lili Rasyidi dan Ira Thania Rasjidi, Hukum Perkawinan di Indonesia (Jakarta : Balai Pustaka Nasional, 2007), hlm. 66
} 
landasan hukum yang kuat dan merupakan bagian dari struktur pemerintahan di tingkat kecamatan.

Pencatatan pernikahan jauh lahir sebelumnya dari pada pembentukan KUA, sehingga sejak tahun 1974 dimana undang - undang tentang perkawinan lahir hingga 2001 terdapat kekosongan hukum, sehingga bagi warga negara yang melangsungkan perkawinan namun belum tercatat dapat memohonkan Isbat Nikah ke Pengadilan Agama pemohon.

Bagi pihak yang tidak mencatatkan perkawinannya secara hukum negara perkawinannya dianggap tidak memiliki ketentuan hukum. Artinya jika sesuatu yang buruk menimpa perkawinannya, seperti suami tidak mau mengakui adanya perkawinan atau suami tidak mau bertanggung jawab terhadap hak hak isteri atau anaknya (hak keperdataan), maka negara tidak akan melindungi hak - hak mereka. Pada kasus seperti ini pihak yang banyak mendapatkan kerugian adalah perempuan dan anak - anak yang dilahirkan dari perkawinan tersebut. Diantara hak - hak perempuan dan anak - anak yang tidak bisa dituntut adalah hak waris, nafkah dan perwalian.

Akan tetapi, tidak dapat dipungkiri masih banyak masyarakat yang belum taat hukum, dibuktikan dengan masih banyaknya perkawinan secara diam - diam (tidak menghadap ke KUA), terlepas dengan segala alasan yang muncul dari ketidaktaatan tersebut, akan tetapi ketidaktaatan tersebut dapat berakibat hukum bagi keberlangsungan keluarga mereka kelak, dimana anak anak mereka akan kesulitan mendapatkan fasilitas pendidikan dan lain - lain.

Ketidaktaatan tersebut dan masih banyaknya perkawinan yang tidak tercatat di KUA menjadi alasan diterbitkannya Surat Edaran Mahkamah Agung yang terbit pada tanggal 13 Maret 2014 untuk seluruh Mahkamah Syari'ah dan Pengadilan Agama se Indonesia Nomor : 03 / Bua.6 / Hs / SP / 2014 tentang tata cara pelayanan dan pemeriksaan perkara Voluntair Isbat Nikah Dalam Pelayanan Terpadu, yang isinya sebagai berikut $:^{12}$

1. Perkara Voluntair isbat nikah harus diajukan oleh kedua belah pihak (suami dan isteri), in person

2. Permohonan diajukan kepada Mahkamah Syari'ah atau Pengadilan Agama yang wilayah yurisdiksinya meliputi tempat kediaman pemohon.

\footnotetext{
12 Salinan Surat Edaran Mahkamah Agung, Kamar Direktorat Badilag Mahkamah Agung Republik Indonesia.
} 
FITRAH Jurnal Kajian Ilmu-ilmu Keislaman Vol. 04 No. 1 Juni 2018

3. Mahkamah syari'ah atau Pengadilan Agama memeriksa, mengadili dan memutus perkara voluntair isbat nikah tersebut dengan memperhatikan hukum acara yang berlaku

4. Perkara voluntair isbat nikah yang diperiksa dengan pelaksanaan sidang keliling atau sidang diluar pengadilan merujuk pada ketentuan Peraturan Mahkamah Agung Nomor 1 Tahun 2014 jo Surat Keputusan Direktur Jenderal Badan Peradilan Mahkamah Agung Nomor 01/SK/TUADA-AG/I/2013 tentang Pedoman Pelaksanaan Sidang Keliling.

Dalam rangka melaksanakan ketentuan Undang - undang Nomor 24 tahun 2013 tentang perubahan atas Undang - undang Nomor 23 tahun 2006 tentang Administrasi Kependudukan dan Peraturan Presiden Nomor 25 tahun 2008 tentang persyaratan dan tata cara Pendaftaran Penduduk dan Pencatatan Sipil untuk mewujudkan tertib administrasi kependudukan secara nasional guna memberikan perlindungan dan pengakuan terhadap penentuan status pribadi dan status hukum atas setiap peristiwa kependudukan dan peristiwa penting yang dialami oleh penduduk.

Memperhatikan tuntutan masyarkat yang semakin tinggi mengenai kepastian hukum bagi pasangan suami isteri yang tidak tercatat di Kantor Urusan Agama, dimana pasangan suami isteri yang ingin perkawinannya dicatat di Kantor Urusan Agama dan mendapat salinan buku nikah memerlukan penetapan Isbat Nikah yang diajukan masyarakat ke Pengadilan Agama melalui terpadu adalah dari kalangan tidak mampu secara finansial.

\section{PEMBAHASAN}

\section{Asas Penegakan Hukum Dalam Produk Perundang - undangan.}

Penegakan hukum adalah suatu rangkaian kegiatan dalam rangka usaha pelaksanaan ketentuan-ketentuan hukum baik yang bersifat penindakan maupun pencegahan yang mencakup seluruh kegiatan baik teknis maupun administratif yang dilaksanakan oleh aparat penegak hukum sehingga dapat melahirkan suasana aman, damai dan tertib untuk mendapatkan kepastian hukum dalam masyarakat, dalam rangka menciptakan kondisi agar pembangunan disegala sektor itu dapat dilaksanakan oleh pemerintah. ${ }^{13}$

Penegakan hukum sebagai suatu proses yang pada hakikatnya merupakan penerapan direksi yang menyangkut membuat keputusan yang tidak

\footnotetext{
${ }^{13}$ Shant Dellyana, Konsep Penegakan Hukum, (Yogyakarta: Liberty 1988). hlm., 32
} 
secara ketat diatur oleh kaidah hukum akan tetapi mempunyai unsurunsur penilaian pribadi (Wayne La-Favre). Secara konsepsional, maka inti dan arti penegakan hukum terletak pada kegiatan menyerasikan hubungan nilai-nilai yang terjabarkan di dalam kaidah-kaidah yang mantap dan sikap tindak sebagai rangkaian penjabaran nilai tahap akhir, untuk menciptakan, melahirkan dan mempertahankan kedamaian pergaulan hidup. ${ }^{14}$

Untuk melihat efektif atau tidaknya sebuah penegakan hukum menurut Friedman tergantung tiga unsur sistem hukum, yakni struktur hukum (struktur of law), substansi hukum (substance of the law) dan budaya hukum (legal culture). Struktur hukum menyangkut aparat penegak hukum, substansi hukum meliputi perangkat perundang-undangan dan budaya hukum merupakan hukum yang hidup (living law) yang dianut dalam suatu masyarakat. ${ }^{15}$

Mengenai struktur hukum, Friedman menjelaskan :

"To begin with, the legal sytem has the structure of a legal system consist of elements of this kind: the number and size of courts; their jurisdiction ...Strukture also means how the legislature is organized ... what procedures the police department follow, and so on. Strukture, in way, is a kind of crosss section of the legal system... a kind of still photograph, with freezes the action." 16

Struktur dari sistem hukum terdiri, jumlah dan ukuran pengadilan, yurisdiksinnya (termasuk jenis kasus yang berwenang mereka periksa), dan tata cara naik banding dari pengadilan ke pengadilan lainnya. Struktur juga berarti bagaimana badan legislative ditata, apa yang boleh dan tidak boleh dilakukan oleh presiden, prosedur ada yang diikuti oleh kepolisian dan sebagainya. Jadi struktur (legal struktur) terdiri dari lembaga hukum yang ada dimaksudkan untuk menjalankan perangkat hukum yang ada. Struktur adalah Pola yang menunjukkan tentang bagaimana hukum dijalankan menurut ketentuanketentuan formalnya. Struktur ini menunjukkan bagaimana pengadilan, pembuat hukum dan badan serta proses hukum itu berjalan dan dijalankan.

Mengenai Substansi hukum Friedman juga menjelaskan bahwa :

14 Soerjono Soekanto, Faktor-Faktor Yang Mempengaruhi Penegakan Hukum, (Jakarta PT. Rajagrafindo Persada, 2012), hlm. 5.

${ }^{15}$ L. Friedman, Teori dan Filsafat Hukum : Telaah kritis atas teori - teori hukum (legal theory), (Jakarta : PT. Raja Grapindo Persada, 1993), hlm. 65

${ }^{16}$ Friedman Lawrence, Law and Society An Introduction, (New Jersey : Prentice Hall Inc, 1987), hlm. 103 
FITRAH Jurnal Kajian Ilmu-ilmu Keislaman

Vol. 04 No. 1 Juni 2018

"Another aspect of the legal system is its substance. By this is meant the actual rules, norm, and behavioral patterns of people inside the system ...the stress here is on living law, not just rules in law books".17

Aspek lain dari sistem hukum adalah substansinya. Yang dimaksud dengan substansinya adalah aturan, norma, dan pola perilaku nyata manusia yang berada dalam system itu. Jadi substansi hukum menyangkut peraturan perundang-undangan yang berlaku yang memiliki kekuatan yang mengikat dan menjadi pedoman bagi aparat penegak hukum.

Sedangkan mengenai budaya hukum, Friedman menjelaskan :

"The third component of legal system, of legal culture. By this we mean people's attitudes toward law and legal system their belief ...in other word, is the climinate of social thought and social force wicch determines how law is used, avoided, or abused". ${ }^{18}$

Kultur hukum menyangkut budaya hukum yang merupakan sikap manusia (termasuk budaya hukum aparat penegak hukumnya) terhadap hukum dan sistem hukum. Sebaik apapun penataan struktur hukum untuk menjalankan aturan hukum yang ditetapkan dan sebaik apapun kualitas substansi hukum yang dibuat tanpa didukung budaya hukum oleh orang-orang yang terlibat dalam sistem dan masyarakat maka penegakan hukum tidak akan berjalan secara efektif.

Hukum sebagai alat untuk mengubah masyarakat atau rekayasa sosial tidak lain hanya merupakan ide-ide yang ingin diwujudkan oleh hukum itu. Untuk menjamin tercapainya fungsi hukum sebagai rekayasa masyarakat kearah yang lebih baik, maka bukan hanya dibutuhkan ketersediaan hukum dalam arti kaidah atau peraturan, melainkan juga adanya jaminan atas perwujudan kaidah hukum tersebut ke dalam praktek hukum, atau dengan kata lain, jaminan akan adanya penegakan hukum (law enforcement) yang baik. Jadi bekerjanya hukum bukan hanya merupakan fungsi perundang-undangannya belaka, melainkan aktifitas birokrasi pelaksananya.

Faktor - faktor yang mempengaruhi ketaatan terhadap hukum secara umum adalah sebagai berikut $:^{19}$

${ }^{17}$ Friedman Lawrence, Law and Society An., hlm. 104

${ }^{18}$ Friedman Lawrence, Law and Society An., hlm. 106

19 Achmad Ali, Menguak Teori Hukum (Legal theory) dan Teori Peradilan (Judicialprudence) termasuk interpretasi undang - undang (Legisprudence), (Jakarta : Prenada Media Group, 2009), hlm. 376 
1. Relevansi aturan hukum secara umum, dengan kebutuhan hukum dari orang - orang yang menjadi target aturan hukum secara umum itu. Oleh karena itu, jika aturan hukum yang dimaksud berbentuk undang - undang maka pembuat undang - undang untuk mampu memahami kebutuhan hukum dari target perberlakuan undang - undang tersebut.

2. Kejelasan rumusan dari substansi aturan hukum, sehingga mudah dipahami oleh target diberlakukannya aturan hukum. Jadi, perumusan substansi aturan hukum itu harus dirancang dengan baik, jika aturannya tertulis, harus ditulis dengan jelas dan mampu dipahami secara pasti, meskipun nantinya tetap akan membutuhkan interpretasi dari penegak hukum yang akan menerapkannya.

3. Sosialisasi yang optimal kepada aturan hukum, tidak mungkin penduduk atau warga masyarakat secara umum mampu mengetahui keberadaan suatu aturan hukum dan substansinya jika aturan hukum tersebut tidak disosialisasikan secara optimal.

4. Jika hukum yang dimaksud adalah perundang - undangan, maka seyogianya aturan yang bersifat melarang, dan jangan bersifat mengharuskan, sebab, aturan hukum yang melarang (prohibitur) lebih mudah dilaksanakan ketimbang aturan hukum yang bersifat mengharuskan (mandatur).

5. Sanksi yang diancamkan oleh aturan hukum itu, harus dipadankan dengan sifat aturan hukum yang dilanggar tersebut, suatu sanksi yang tepat untuk suatu tujuan tertentu belum tentu tepat untuk tujuan lain.

6. Berat ringannya sanksi yang diancam dalam aturan, harus proporsional dan memungkinkan untuk dilaksanakan.

7. Kemungkinan bagi penegak hukum untuk memperoses jika terjadi pelanggaran terhadap aturan hukum tersebut, adalah memang memungkinkan, karena tindakan yang diatur dan diancamkan sanksi memang tindakan yang konkrit, dapat dilihat dan diamati, oleh karenanya memungkinkan untuk diproses dalam setiap tahapan (penyelidikan, penyidikan, penuntutan dan penghukuman).

8. Aturan hukum yang mengandung norma moral berwujud larangan, relatif akan jauh lebih efektif ketimbang aturan hukum yang bertentangan dengan nilai moral yang dianut oleh orang - orang yang menjadi target diberlakukannya aturan hukum tersebut, aturan hukum yang sangat efektif 
FITRAH Jurnal Kajian Ilmu-ilmu Keislaman

Vol. 04 No. 1 Juni 2018

adalah aturan hukum yang melarang dan mengancamkan sanksi bagi tindakan yang juga dilarang dan diancamkan sanksi oleh norma lain, seperti norma moral, norma agama, norma adat istiadat, kebiasaan dan lainnya. Aturan hukum yang tidak diatur dan dilarang oleh norma lain akan lebih tidak efektif.

9. Efektif atau tidak efektifnya suatu aturan hukum secara umum, juga tergantung pada optimal dan profesional tidaknya aparat penegak hukum untuk menegakkan berlakunya aturan hukum tersebut, mulai dari tahap pembuatannya, sosialisasinya, proses penegakan hukumnya dan penerapannya terhadap suatu kasus konkret.

10. Efektif atau tidaknya suatu aturan hukum secara umum juga mensyaratkan adanya standar hidup sosio ekonomi yang minimal didalam masyarakat. Dan sebelumnya, ketertiban umum sedikit atau banyak haruslah tetap terjaga karena tidak mungkin efektivitas hukum akan terwujud secara optimal jika masyarakat dalam keadaan kaos atau situasi perang dahsat.

Jika ingin mengkaji dan menganalisis efektifnya sebuah perundang undangan banyak tergantung pada beberapa faktor, antara lain $:^{20}$

1. Pengetahuan tentang substansi (isi) perundang - undangan.

2. Cara - cara untuk memperoleh pengetahuan tersebut.

3. Institusi yang terkait dengan ruang lingkup perundang - undangan didalam masyarakatnya.

4. Bagaimana proses lahirnya suatu perundang - undangan yang tidak boleh dilahirkan secara tergesa - gesa untuk kepentingan instan (sesaat) yang diistilahkan oleh Gunnar Myrdall sebagai Sweep Legislation (undang undang sapu) yang memiliki kualitas buruk dan tidak sesuai dengan kebutuhan masyarkatnya.

Secara eksplisit, dapat disimpulkan bahwa faktor yang banyak mempengaruhi efektivitas suatu perundang - undangan adalah profesional dan optimal dalam melaksanakan peran wewenang dan fungsi dari para penegak hukum, baik dalam menjalankan tugas yang dibebankan terhadap diri mereka sendiri maupun dalam menegakkan perundang - undang tersebut.

Adapun efektivitas perundang - undangan dapat ditinjau dari dua perspektif, yaitu $:^{21}$

${ }^{20}$ Achmad Ali, Menguak Teori Hukum (Legal theory) dan..., hlm. 378

${ }^{21}$ Achmad Ali, Menguak Teori Hukum (Legal theory) dan...., hlm. 379 
1. Perspektif organisatoris, yaitu yang memandang perundang - undangan sebagai "institusi" yang ditinjau dari ciri - cirinya.

2. Perspektif individu atau ketaatan, yaitu yang lebih banyak berfokus pada segi individu atau pribadi, dimana pergaulan hidupnya diatur oleh perundangan - undangan

\section{Efektivitas SEMA Nomor 3 Tahun 2014}

Jika dilihat dari proses pelaksanaannya, maka kita akan disuguhkan dengan fenomema dimana masih banyak masyarakat yang tidak taat dan tidak sadar hukum, tentu ini tidak hanya salah masyarakat yang tidak mengerti hukum, sebab mereka tidak memiliki modal pendidikan untuk mengetahui itu, dan mereka juga tidak mengerti tindakan mereka tersebut bertentangan dengan undang - undang bahkan pelakunya bisa dipidana.

Berdasarkan data pemohon isbat yang di rilis oleh Direktorat Pembinaan Administrasi Peradilan Agama Ditjen Badilag, sepanjang tahun 2017 pelayanan terpadu terselenggara di 362 lokasi dan jumlah perkara yang disidangkan sebaganya 16. 392, sedangkan pada tahun sebelumnya, pelayanan terpadu terselenggara di 69 lokasi dan jumlah perkara yang disidangkan sebanyak 1.976 yang diselesaikan lewat pola sidang keliling sangat begitu signifikan, maka jika dilihat dari angka tersebut kita dapat menyimpulkan bahwa tujuan dikeluarkannya Surat Edaran Mahkamah Agung Nomor 3 Tahun 2014 yang berlaku secara general di seluruh Pengadilan Agama di Indonesia sangat efektif.

Tentu SEMA Nomor 3 Tahun 2014 ini dikeluarkan memiliki tujuan yang jelas, dan Mahkamah Agung juga telah melihat bahwa keberadaan SEMA dapat menjadi alternatif masyarkat yang telah melaksanakan pernikahan tanpa pencatatan oleh pihak KUA, namun mereka membutuhkan pengakuan baik secara hukum maupun secara administrasi, sebab jika tidak maka pernikahan mereka tidak akan diakui oleh Negara, dan anak yang mereka lahirkan juga tidak akan mendapatkan fasilitas yang menunjang masa depannya seperti pendidikan, kesehatan dan lain - lain.

\section{Implikasi Hukum dari Pemberlakuan Surat Edaran Mahkamah Agung Nomor} 3 Tahun 2014 terhadap eksistensi Undang - undang Nomor 1 Tahun 1974

Untuk melihat produk-produk hukum Mahkamah Agung ("MA"), kita harus melihat bagaimana peraturan perundang-undangan mengatur dan 
FITRAH Jurnal Kajian Ilmu-ilmu Keislaman Vol. 04 No. 1 Juni 2018

memberi kewenangan kepada MA. Pasal 24 A Undang-Undang Dasar RI 1945 (“UUD 1945”) mengatur MA berwenang mengadili pada tingkat kasasi, menguji peraturan perundang-undangan di bawah undang-undang terhadap undang-undang, dan mempunyai wewenang lainnya yang diberikan undangundang. Ini juga sejalan dengan pandangan bahwa peraturan perundangundangan hanya dapat dibentuk oleh lembaga-lembaga yang memperoleh kewenangan perundang-undangan (wetgevingsbevoegheid), yaitu kekuasaan untuk membentuk hukum atau rechtsvorming (lihat misalnya Maria Farida Indrati Soeprapto, 1998: 54).

Mari kita lihat Undang-Undang (“UU”) yang mengatur Mahkamah Agung, mulai dari UU No. 14 Tahun 1985, hingga dua kali perubahannya yakni UU No. 5 Tahun 2004, dan UU No. 3 Tahun 2009(selanjutnya disebut UUMA). Ada beberapa kewenangan dan tugas yang diberikan Undang-Undang kepada MA, antara lain:

1. Mahkamah Agung memberikan pertimbangan hukum kepada presiden dalam permohonan grasi dan rehabilitasi (pasal 14 ayat 1 UU ayat 1 UUD jo pasal 35 UUMA

2. Mahkamah Agung dapat memberikan pertimbangan - pertimbangan dalam bidang hukum baik diminta maupun tidak kepada lembaga tinggi negara yang lain (Pasal 37 UUMA)

3. Mahkamah Agung berwenang memberikan petunjuk di semua lingkungan peradilan dalam rangka pelaksanaan ketentuan UU Kekuasaan Kehakiman (Pasal 38 UUMA)

4. Mahkamah Agung berwenang memberikan petunjuk teguran atau peringatan yang dipandang perlu kepada pengadilan disemua lingkungan peradilan.

Dalam literatur kewenangan dan tugas demikian disebut sebagai fungsi pengaturan atau regelende functie MA. Ini juga sejalan dengan rumusan Pasal 79 UUMA yang mengatur "Mahkamah Agung dapat mengatur lebih lanjut hal - hal yang diperlukan bagi kelancaran penyelenggaraan peradilan apabila terdapat hal - hal yang belum cukup diatur dalam undang - undang ini". Dalam konteks itulah kita seyogyanya membaca produk hukum Mahkamah Agung berikut :

1. Peraturan Mahkamah Agung (PERMA)

2. Surat Edaran Mahkamah Agung (SEMA)

3. Fatwa dan 


\section{SK KMA}

Peraturan Mahkamah Agung atau PERMA pada dasarnya adalah bentuk peraturan yang berisi ketentuan hukum acara, sedangkan Surat Edaran Mahkamah Agung atau SEMA bentuk edaran pimpinan Mahkamah Agung ke seluruh jajaran peradilan yang berisi bimbingan dalam penyelenggaraan peradilan yang lebih bersifat adiministrasi. Adapun Fatwa berisi pendapat hukum Mahkamah Agung yang diberikan atas permintaan lembaga negara dan Surat Keputusan Ketua Mahkamah Agung atau SK KMA adalah surat keputusan (beschikking) yang dikeluarkan oleh ketua Mahkamah Agung mengenai satu hal tertentu.

Berdasarkan Undang - undang Nomor 10 Tahun 2004 tentang pembentukan peraturan perundang - undangan (UU 10/2004) yang telah diganti dengan UU Nomor 12 Tahun 2011 tentang Pembentukan Peraturan Perundang - Undangan (UU 12/2011). Pasal 8 ayat (1) UU 12/2011 mengatur "Jenis peraturan perundang - undangan selain yang disebut dalam pasal (1) mencakup praturan yang ditetapkan Mahkamah Agung". Rumusan ini senafas dengan pasal 7 ayat (4) dan penjelasan UU 10/2004. Selanjutnya pasal 8 ayat (2) UU 12/2011 menegaskan peraturan perundang - undangan tersebut diakui keberadaannya dan mempunyai kekuatan hukum mengikat sepanjang diperintahkan oleh peraturan perundang - undangan yang lebih tinggi atau dibentuk berdasarkan kewenangan.

Frasa "kekuatan Hukum"di sini menurut Yuliandri adalah sesuai dengan hierarki peraturan perundang - undangan yang perjenjangan setiap jenis peraturan perundang - undangan yang didasarkan pada asas bahwa peraturan perundang - undangan yang lebih rendah tidak boleh bertentangan dengan peraturan perundang - undangan yang lebih tinggi. ${ }^{22}$ Yuliandri juga berpendapat jenis peraturan lain (dalam konteks ini peraturan yang diterbitkan Mahkamah Agung) seharusnya juga tunduk pada prinsip hierarki.

Jimly Asshiddiqie memasukkan peraturan Mahkamah Agung sebagai peraturan yang bersifat khusus sehingga tunduk pada prinsip Lex Specialis Derogat Legi Generalis. Namun jimly mengkritik bentuk surat edara

${ }_{22}$ Yuliandri, Asas - asas Pembentukan Peraturan Perundang - undangan yang baik : gagasan pembentukan undang - undang berkelanjutan, (Jakarta : Raja Grapindo Persada, 2010), h. 67 - 68 
FITRAH Jurnal Kajian Ilmu-ilmu Keislaman

Vol. 04 No. 1 Juni 2018

yang materinya bersifat pengaturan. Jika materinya berisi peraturan sebaiknya bentuk produk hukumnya adalah peraturan. ${ }^{23}$

Demikian juga Surat Edaran Mahkamah Agung RI Nomor 3 Tahun 2014 ini tidak bertentangan dengan Undang - undang manapun, namun secara substansinya surat edaran ini memperlemah eksistensi Undang undang yaitu UU Nomor 1 tahun 1974 dimana perkawinan harus dicatatkan di Kantor Urusan Agama.

\section{PENUTUP}

Bahwa Surat Edaran Mahkamah Agung Nomor 3 Tahun 2014 sangat efektif dalam memenuhi kebutuhan masyarakat yang menginginkan pengakuan atas perkawinan yang telah mereka lakukan yang menurut Agama sah, namun tidak sah secara hukum karena tidak diketahui oleh Kantor Urusan Agama dan juga tidak dicatat sebagai perkawinan yang sah, sehingga keberadaan SEMA Nomor 3 Tahun 2014 dapat mengesahkan perkawinan tersebut dalam bentuk sidang isbat nikah.

Secara substansinya, keberadaan Surat Edaran Mahkamah Agung RI Nomor 3 Tahun 2014 ini tidak bertentangan dengan undang - undang manapun, sebab surat edaran ini hanya mengatur hal tekhnis dari proses peradilan, namun hakikat dari pelaksanaanya dapat memperlemah eksistensi Undang - Undang Nomor 1 Tahun 1974 tentang perkawinan yang menjadi wewengan Kantor Urusan Agama.

Secara hierarki perundang - undangan, keberadaan SEMA Nomor 3 Tahun 2014 sangat berimplikasi terhadap eksistensi Undang - undang Nomor 1 Tahun 1974 sebagai sebuah institusi hukum, sehingga ada 1 point dari perintah undang - undang tersebut menjadi lemah dan akan menjadi alasan masyarakat untuk tidak mematuhinya.

${ }^{23}$ Jimly Asshiddiqie, Konstitusi dan Konstitusionalisme Indonesia (Jakarta : Mahkamah Konstitusi RI dan Pusat Studi Hukum Tata Negara FHUI, 2004), hlm.278 - 279 


\section{DAFTAR PUSTAKA}

Aburrahman, Perkawinan Dalam Syari'at Islam, Jakarta : Rineka Cipta, 1992.

Ali, Achmad, Menguak Teori Hukum (Legal theory) dan Teori Peradilan (Judicialprudence) termasuk interpretasi undang - undang (Legisprudence), Jakarta : Prenada Media Group, 2009.

Asshiddiqie, Jimly, Konstitusi dan Konstitusionalisme Indonesia Jakarta : Mahkamah Konstitusi RI dan Pusat Studi Hukum Tata Negara FHUI, 2004.

Dellyana, Shant, Konsep Penegakan Hukum, Yogyakarta: Liberty 1988.

Friedman, Lawrence, Teori dan Filsafat Hukum : Telaah kritis atas teori - teori hukum (legal theory), Jakarta : PT. Raja Grapindo Persada, 1993. , Law and Society An Introduction, New Jersey : Prentice Hall Inc, 1987.

Mahkamah Agung RI, Direktorat Jenderal Badan Peradilan Agama

Rasyidi, Lili dan Ira Thania Rasjidi, Hukum Perkawinan di Indonesia, Jakarta : Balai Pustaka Nasional, 2007.

Salim, Nasruddin, "Isbat Nikah Dalam Kompilasi Hukum Islam (Tinjauan Yuridis Filosofis Dan Sosiologis)", dalam Mimbar Hukum Aktualisasi Hukum Islam, No. 62 THN XIV, Jakarta : Al- Hikmah dan DITBINBAPERA Islam, 2004.

Soekanto, Soerjono, Faktor-Faktor Yang Mempengaruhi Penegakan Hukum, Jakarta PT. Rajagrafindo Persada, 2012.

Subekti R., Pokok - pokok Hukum Perdata Jakarta : PT. Pradnya Paramita,1999.

Yuliandri, Asas - asas Pembentukan Peraturan Perundang - undangan yang baik: gagasan pembentukan undang - undang berkelanjutan, Jakarta : Raja Grapindo Persada, 2010. 
FITRAH Jurnal Kajian Ilmu-ilmu Keislaman

Vol. 04 No. 1 Juni 2018

Pendidikan agama Bagi Anak dalam Keluarga

Di Gampong Aneuk Galong Baro, Aceh Besar

Aulia Rahmi

Fakultas Agama Islam Universitas Serambi Mekkah Banda Aceh 